\title{
Thermally Dimorphic Human Fungal Pathogens - Polyphyletic Pathogens with a Convergent Pathogenicity Trait
}

\author{
Anita Sil ${ }^{1}$ and Alex Andrianopoulos ${ }^{2}$ \\ ${ }^{1}$ Department of Microbiology and Immunology, University of California, San Francisco, California 94143 \\ ${ }^{2}$ Department of Genetics, The University of Melbourne, Victoria 3010, Australia \\ Correspondence: sil@cgl.ucsf.edu
}

Fungi are adept at changing their cell shape and developmental program in response to signals in their surroundings. Here we focus on a group of evolutionarily related fungal pathogens of humans known as the thermally dimorphic fungi. These organisms grow in a hyphal form in the environment but shift their morphology drastically within a mammalian host. Temperature is one of the main host signals that initiates their conversion to the "host" form and is sufficient in the laboratory to trigger establishment of this host-adapted developmental program. Here we discuss the major human pathogens in this group, which are Blastomyces dermatiditis, Coccidioides immitis/posadasii, Histoplasma capsulatum, Paracoccidioides brasiliensis/lutzii, Sporothrix schenckii, and Talaromyces marneffei (formerly known as Penicillium marneffei). The majority of these organisms are primary pathogens, with the ability to cause disease in healthy humans who encounter them in endemic areas.

$\mathrm{D}$ morphism is defined as the ability of a fungus to generate free-living vegetative cell types that are either yeast or hyphal (Fig. 1), although we discuss some exceptions to this precise definition below. The most parsimonious explanation for the origin of fungi begins with a unicellular eukaryotic cell from which multicellular filamentous forms evolved. Presumably, the first filamentous forms would have been locked into that mode of growth by simple mutations in the cell division machinery, and a regulated transition between the unicellular and multicellular vegetative forms (dimorphism) evolved over time. For the filamentous growth form, the ability to generate independent, uni- cellular forms has reemerged several times in the guise of modern developmental programs such as asexual and sexual reproduction, which produce differentiated, dormant spores.

Dimorphism in fungi is likely to have arisen independently a number of times. The polyphyletic nature of dimorphism is evident in the distribution of organisms with this capability across the fungal kingdom (see Fig. 2). Dimorphic fungi exist in the three major phyla of fungi: the Ascomycota, Basidiomycota, and Zygomycota. In the Ascomycota, they are distributed across several orders and are closely related to many nondimorphic fungi. The largest cluster of thermally dimorphic fungi includes Histo-

Editors: Arturo Casadevall, Aaron P. Mitchell, Judith Berman, Kyung J. Kwon-Chung, John R. Perfect, and Joseph Heitman

Additional Perspectives on Human Fungal Pathogens available at www.perspectivesinmedicine.org

Copyright (C) 2015 Cold Spring Harbor Laboratory Press; all rights reserved; doi: 10.1101/cshperspect.a019794

Cite this article as Cold Spring Harb Perspect Med 2015;5:a019794 
A. Sil and A. Andrianopoulos

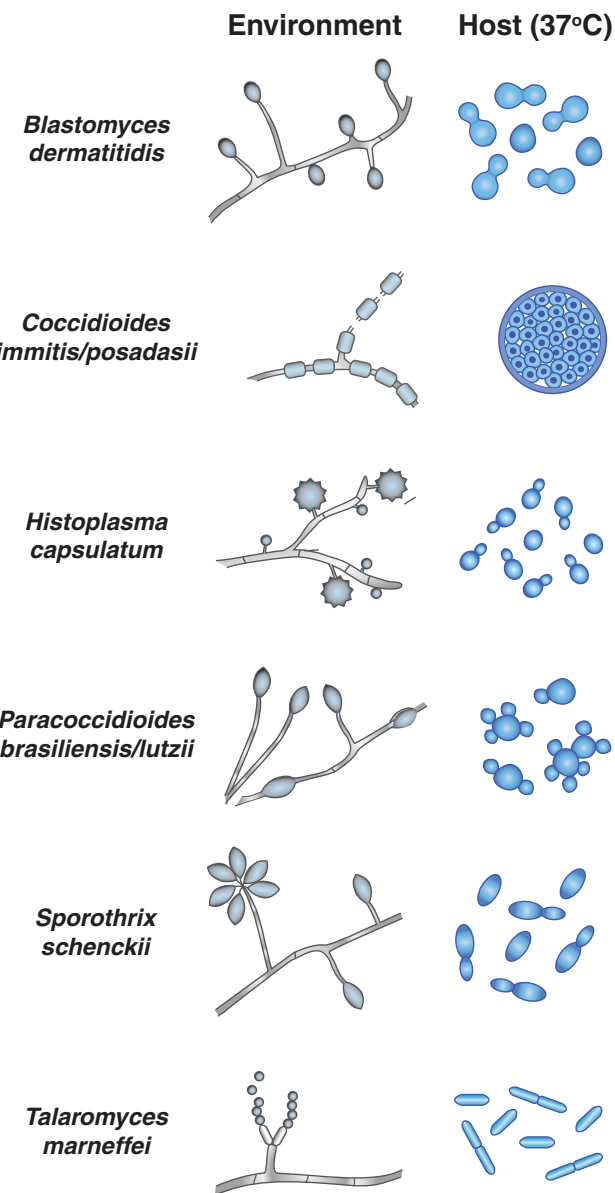

Figure 1. Simplified schematic of temperature-regulated forms of thermally dimorphic fungal pathogens. Simple cartoons of the environmental and host forms of each fungal species are shown. In the environmental hyphal form of these organisms, oval swellings depict vegetative conidia. In the case of $H$. capsulatum, tuberculate macroconidia and microconidia are shown. In the case of Coccidioides spp., disarticulating arthroconidia are shown. Some of the characteristic differences between yeast-phase growth are depicted: Blastomyces dermatitidis yeast cells have a broad bud neck, Paracoccidioides yeast can be multibudded, and T. marneffei yeast divides by fission rather than budding. Note that the relative scale of different cell types (within and between species) is not meant to be accurate. (Illustration provided by Davina Hocking Murray.)

plasma capsulatum, Blastomyces dermatiditis, Coccidioides, and Paracoccidioides species of the order Onygenales. Similarly, there are a number of dimorphic species in the Ophiostomatales order including the various Sporothrix species. In contrast, Talaromyces marneffei is the only known dimorphic species in the large order of Eurotiales and is, in fact, the only dimorphic fungus in which yeast cells divide by fission rather than budding. There are far fewer known dimorphic fungi in the other phyla with the best known basidiomycete being the maize smut $U s$ tilago maydis and zygomycete animal pathogens represented by various Mucor species. Indeed, many of the dimorphic fungi are pathogens of animals or plants.

As mentioned above, dimorphism in its strictest sense involves the ability of a fungus to generate two types of vegetative cells-those that are either yeast or hyphal in morphology. Coccidioides species do not precisely fit this definition because they do not produce free-living 


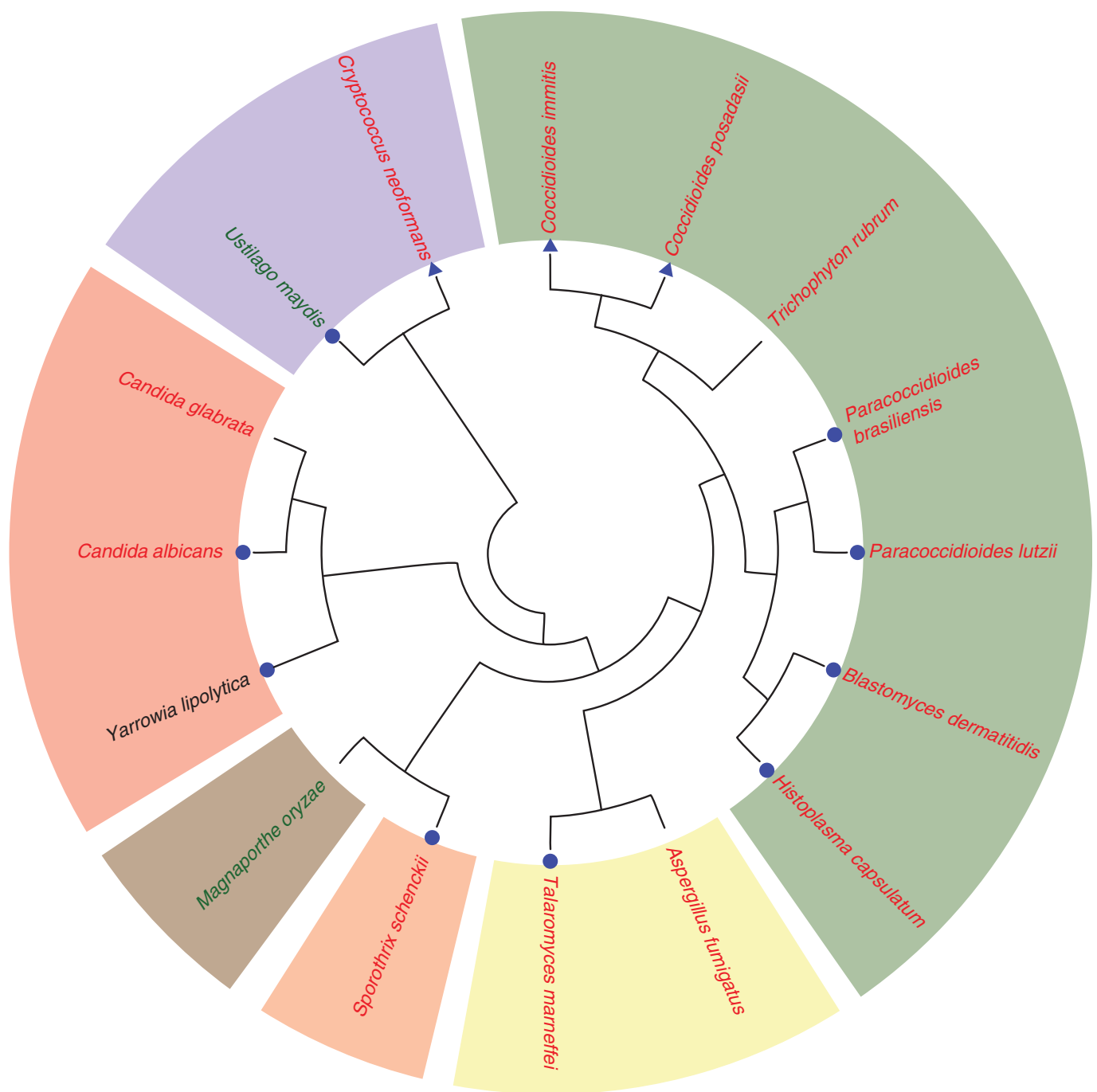

Figure 2. Molecular phylogenetic analysis of dimorphic fungal pathogens. The evolutionary tree is based on a protein comparison from the major dimorphic human pathogens and includes a number of other fungal pathogens for reference. Human pathogens (red typeface), plant pathogens (green typeface), and nonpathogens (black typeface) are shown and marked as true dimorphic species with free-living vegetative cell types (blue circle) and species with morphological transitions that are not free-living vegetative cell types (blue triangle). With the exception of C. neoformans and U. maydis, which are in the phylum Basidiomycota, all of the other species are in the phylum Ascomycota. These species cover a diverse range of orders (Onygenales, green; Eurotiales, yellow; Ophiostomales, orange; Magnaporthales, brown; and Saccharomycetales, red). To generate the phylogenetic relationships between organisms, the Pfam domain Gcd10p was used to identify Gcd10 sequences from the 16 species of interest. CLUSTALX 2.1 (Larkin et al. 2007) was used to align the full-length protein sequences and generate a bootstrapped neighbor-joining tree (1000 bootstraps; all internal nodes had a bootstrap value of at least 700). (Mark Voorhies contributed to this analysis.) 
vegetative yeast cells but rather spherules that encompass numerous single cells known as endospores (Fig. 1). A number of other fungi exhibit aspects of dimorphism in their growth and morphogenesis patterns. A well-characterized example is pseudohyphal growth in the ascomycete yeast Saccharomyces cerevisiae; when diploid S. cerevisiae cells experience nitrogen limitation, they undergo a morphological transition to an elongated cell shape, with unipolar budding and incomplete separation of mother and daughter cells. This leads to hyphal-like filaments and is a program exhibited by a number of yeasts including the human pathogen Candida albicans, which can form pseudohyphae as well as true hyphae. The basidiomycete yeast Cryptococcus neoformans is also capable of forming hyphal filaments as part of a mating program.

As described below, thermally dimorphic fungal pathogens are endemic worldwide. Nonetheless, our understanding of the environmental niche and epidemiology of these dimorphic pathogens is far from complete. Because these organisms replicate in the absence of a mammalian host, the environmental pressures that have selected for host-specific traits is unclear. All of these fungi show robust, albeit sometimes slow, prototrophic growth in the hyphal form in the environment. These hyphae produce asexual spores (conidia) that often constitute the most common infectious propagule for a given organism. Conidiating hyphae are thought to exist in a mix of elusive nonhost environments and growth on dead hosts. Interestingly, it has been proposed that eukaryotic predators such as amoebae and slime molds could provide a selective pressure for virulence traits that are required to survive the antimicrobial onslaught from mammalian phagocytic cells (Steenbergen et al. 2004).

\section{Blastomyces dermatitidis}

The first known case report of infection with B. dermatitidis occurred in 1894 when T.C. Gilchrist reported a patient with a skin disease supposedly caused by a protozoan infection. However, Gilchrist and colleagues soon noticed a budding yeast form in tissues and cultured a hyphal organism from patient samples that they named B. dermatitidis (Gilchrist 1894; Gilchrist and Stokes 1896, 1898). Following Gilchrist's discovery, it took at least an additional 50 years to understand that the cutaneous manifestation of disease was associated with pulmonary involvement, suggesting that all cases of skin involvement resulted from dissemination from the lungs. It is now clear that blastomycosis is primarily a lung infection that can disseminate to the skin, osteoarticular structures, genitourinary tract, and other organs (Smith and Kauffman 2010).

B. dermatitidis is challenging to isolate from the environment, making the epidemiology of blastomycosis less well defined than histoplasmosis or coccidiomycosis. Based mainly on case reports, $B$. dermatitidis is known to be endemic in the Mississippi and Ohio River Valleys, the Midwestern states, the Canadian provinces that border the Great Lakes, and the area of New York and Canada adjacent to the St. Lawrence Seaway (Klein et al. 1986, 1987; Crampton et al. 2002; Cano et al. 2003; Dworkin et al. 2005). Additionally, sporadic cases of blastomycosis have been reported from around the world (De Groote et al. 2000; Arnett et al. 2008; Smith and Kauffman 2010). The majority of cases are asymptomatic, but individuals who are either exposed to a large dose of infectious particles or have a defect in cell-mediated immunity develop a more severe, progressive disease (Maresca and Kobayashi 2000; Smith and Kauffman 2010). Acute respiratory distress syndrome can develop in rare cases (Smith and Kauffman 2010), but chronic skin and bone lesions are the most common extrapulmonary complications. The incidence of infection in males is higher than females. Additionally, dogs in endemic regions are susceptible to blastomycosis, making it an important veterinary problem (Baumgardner et al. 1995).

B. dermatitidis undergoes temperature-dependent morphogenesis, growing in a hyphal form in the laboratory at temperatures below $30^{\circ} \mathrm{C}$ and in a yeast form at $37^{\circ} \mathrm{C}$ (Fig. 1) (Maresca and Kobayashi 2000; Nemecek et al. 2006). Like the other thermally dimorphic fungi, its morphology is reversible by changing the tem- 
perature of its environment. Infection occurs when conidia or hyphal fragments are inhaled, and conversion to the yeast form occurs within the host. In contrast to H. capsulatum, which is found intracellularly within phagocytes during infection, $B$. dermatitidis grows as extracellular yeasts in microabcesses (Maresca and Kobayashi 2000; Smith and Kauffman 2010). B. dermatitidis yeasts tend to have a broad neck between the mother and bud (Fig. 1), and the yeast cells are usually, but not always, larger than those of $H$. capsulatum.

A number of fundamental tools have made it possible to identify virulence factors and explore basic processes in B. dermatitidis, including identification of the immunomodulatory adhesin Bad1 as well as factors that regulate morphogenesis and iron homeostasis (Brandhorst et al. 2002; Sullivan et al. 2002; Krajaejun et al. 2007; Gauthier et al. 2010). A huge advance to understanding temperature-regulated morphogenesis was the identification of a hybrid histidine kinase that is required for yeastphase growth and virulence gene induction in response to temperature in both $B$. dermatitidis and H. capsulatum (Nemecek et al. 2006). Additionally, seminal studies of the host response to Blastomyces and other thermally dimorphic fungi have yielded rich insight into the immunobiology of fungal infections (Wuthrich et al. 2011, 2012; Wang et al. 2014).

\section{Coccidioides immitis/posadasii}

In 1891, a medical student in Argentina named Alejandro Posadas saw a patient with an unusual skin lesion. Posadas and Robert Wernicke noted a coccidia-like "parasite" in the lesion (Posadas 1892; Wernicke 1892). The first North American case was reported in 1894 (Rixford 1894). Over the next 20 years, both the dimorphism of the organism (Ophuls and Moffitt 1900 ) and its prevalence in California (Dickson 1915) became obvious.

Coccidioides is a New World pathogen. The genus Coccidioides was recently resolved into two species (Fisher et al. 2002): immitis, endemic in central and southern California and Northern Mexico; and posadasii, found throughout
Thermally Dimorphic Human Fungal Pathogens

Arizona, Texas, Mexico, and parts of South America (Chiller et al. 2003; Galgiani et al. 2005; Pfaller and Diekema 2010; MarsdenHaug et al. 2013). Coccidioides is associated with small mammals in the environment (Ashburn and Emmons 1942; Emmons 1962), although the precise nature of that association and its role in the ecology of the organism is somewhat controversial.

The disease caused by Coccidioides species, coccidioidomycosis, is also known as San Joaquin Valley fever, or simply Valley fever, because of its prevalence in the Central Valley of California. Notably, Coccidioides infections are on the rise in endemic areas, with $>90 \%$ increase in incidence in Arizona and California between 2001 and 2006. The resultant public health impact is enormous (Hector et al. 2011).

Coccidioides spores (arthroconidia) are produced from alternating cells of hyphae (Fig. 1). As the hypha differentiates, individual cells separate from each other, and alternating cells become 3-5 $\mu \mathrm{m}$ barrel-shaped arthroconidia while the remaining cells undergo autolysis. Once inhaled into a mammalian host, arthroconidia undergo a dramatic transformation, ultimately producing a structure that is unique to the genus Coccidioides (Fig. 1). Arthroconidia undergo isotropic growth, expanding in size and modifying the cell wall to produce a spherule, a cellular structure up to $100 \mu \mathrm{m}$ in diameter. The spherule contains 100 to 300 singlecelled units known as endospores. Rupture of the spherule in host tissues releases these endospores, each of which is capable of developing into a new spherule (Nguyen et al. 2013). The spherule itself is refractory to phagocytosis. Spherule formation can be induced in vitro by culturing the fungus in liquid modified Converse medium at $37^{\circ} \mathrm{C}-40^{\circ} \mathrm{C}$ (Converse 1955; Sun et al. 1976).

As is the case for the majority of fungi discussed in this article, the predominant route of infection with Coccidioides spp. is inhalation. The majority of cases are asymptomatic, but some patients develop a complicated pneumonia. Disseminated coccidioidomycosis refers to disease outside of the chest, most commonly to sites such as the skin, joints, bones, and menin- 
ges. Less common is dissemination to the larynx, abdomen, adnexa, and pericardium. African American individuals have a greater risk of developing disseminated coccidioidomycosis than other ethnic groups, suggesting that a genetic component of the host influences the severity of disease outcome (Pappagianis et al. 1979; Pappagianis 1988; Kirkland and Fierer 1996; Nguyen et al. 2013). Similar to the other thermally dimorphic fungal pathogens, individuals with defective cell-mediated immunity are more susceptible to severe disease.

A robust molecular toolbox exists for Coccidioides spp. gene disruption, Agrobacteriummediated transformation, and transcriptional profiling have defined a number of factors critical for pathogenesis, such as the immunomodulatory spherule outer wall glycoprotein (SOWgp) and a urease (URE) that is thought to contribute to host tissue damage (Abuodeh et al. 2000; Hung et al. 2007, 2012). Gene expression studies of Coccidioides hyphae and spherules are defining the transcriptional program of the distinct morphological states of this organism (Johannesson et al. 2006; Whiston et al. 2012; Viriyakosol et al. 2013), which will provide critical clues as to the molecular program that is initiated in response to host signals such as temperature. Additionally, population genomics studies are being used to great effect to define genes that may underlie the virulence of individual Coccidioides isolates (Sharpton et al. 2009; Neafsey et al. 2010).

\section{Histoplasma capsulatum}

Histoplasmosis was first described in 1906 by Samuel Darling, an American physician working at the Ancon Canal Zone Hospital in Panama (Darling 1906). During an autopsy of a patient from Martinique who died from a devastating infection, Darling found intracellular organisms that appeared to have capsules. $\mathrm{He}$ misidentified this organism as a new protozoan parasite and named it $H$. capsulatum owing to its residence within "histiocytes," or macrophages. Over the next few decades, it became obvious that $H$. capsulatum is actually an environmental fungus with no capsule. The organ- ism was first isolated from soil by Chester Emmons in 1948 (Emmons 1949).

Histoplasmosis in humans is caused by two distinct varieties of $H$. capsulatum that manifest in very different clinical outcomes: $H$. capsulatum variety capsulatum and $H$. capsulatum variety duboisii (Kauffman 2007). H. capsulatum $(\mathrm{Hc})$ var. capsulatum is found globally (mainly North, South, and Central America, Southeast Asia, and Africa) and is associated with pulmonary and systemic (i.e., classical) histoplasmosis. In contrast, $H c$ var. duboisii is predominantly found in Western and Central Africa. Because $H c$ var. duboisii causes skin and bone lesions, it was initially distinguished from variety capsulatum on the basis of disease symptoms (Cockshott and Lucas 1964). The disease triggered by variety $H c$ var. duboisii is given the name African histoplasmosis, and little is known about this variety on a molecular level. Both variety capsulatum and duboisii strains have been sequenced by the Broad Institute and the Washington University St. Louis Genome Sequencing center, which will shed light on fundamental molecular differences between $H$. capsulatum isolates. Additionally, phylogenetic analyses based on genome sequence variation of four protein-coding genes were performed on 137 Histoplasma isolates from six continents (Kasuga et al. 2003). These isolates fell into eight clades, seven of which represent distinct phylogenetic species. Although all $H c$ var. duboisii isolates were represented in the African clade, this clade also included variety $H c$ var. capsulatum individuals. In addition to these two varieties, a third variety, $H c$ var. farciminosum, which is a pathogen of horses, was found distributed within three clades. More molecular work is necessary to understand the biological differences between these varieties and their relationship to disease.

From here on, we focus on classical histoplasmosis caused by $H c$ var. capsulatum, referred to as $H$. capsulatum for simplicity. Although the organism is found all over the world, it tends to cause the highest disease burden in Central and North America. Along with B. dermatitidis and Coccidioides spp., H. capsulatum is thought to be the most common cause 
of fungal pulmonary infections in immunocompetent individuals. A study of U.S. hospitalizations for endemic mycoses reveals that these fungi cause significant morbidity and mortality in healthy hosts in endemic regions (Chu et al. 2006), with approximately 25,000 estimated life-threatening infections per year in the Midwestern United States caused by $H$. capsulatum infection (Brown et al. 2012). In the United States, H. capsulatum is endemic in the Ohio and Mississippi River Valleys. The organism is found in soil containing large amounts of bird or bat guano, and bats have been proposed as a vector of spread, both because the fungus grows well in soil contaminated with bat guano, and because bats themselves can be colonized with H. capsulatum (Hoff and Bigler 1981). The vast majority of human infections are asymptomatic, but acute severe pulmonary infection occurs in either an immunosuppressed host or an immunocompetent host who inhales a large inoculum of $H$. capsulatum cells. Outbreaks of anywhere from a few to tens of thousands of people have occurred (Brodsky et al. 1973; Wheat et al. 1981; Wheat 1997).

The hyphal form of $H$. capsulatum undergoes asexual sporulation to give rise to at least two types of conidia, macro- and microconidia (Fig. 1), which are distinguished mainly on the basis of size (Pine 1960). Microconidia range in size from 2 to $6 \mu \mathrm{m}$, whereas macroconidia have been reported to range in size from 8 to $14 \mu \mathrm{m}$ to $10-25 \mu \mathrm{m}$, depending on the strain and growth conditions. It is thought that the microconidia are the appropriate size to lodge in the alveoli of the lungs and thus represent the most prevalent infectious propagule. Conidia and/or hyphal fragments are inhaled by the host and then taken up by macrophages and other phagocytic cells (Eissenberg and Goldman 1991; Bullock 1993; Woods 2003). Once inside the host, both spores and filaments give rise to yeast cells, which evade phagocytic killing and multiply within alveolar macrophages. Subsequently, yeast cells use phagocytic cells as vehicles to spread to multiple organs of the reticuloendothelial system such as the spleen, liver, lymph nodes, and bone marrow. Hematogenous dissemination from the lungs via infected macrophages is thought to occur even in asymptomatic infections (Kauffman 2007). In patients with disseminated disease, other organs such as the skin, heart, brain, adrenal glands, and gastrointestinal tract can be colonized. In the majority of hosts, cell-mediated immunity and the corresponding activation of macrophages serve to curtail the infection (Eissenberg and Goldman 1991; Newman 1999; Deepe 2000; Huffnagle and Deepe 2003). Nonetheless, $H$. capsulatum can remain latent and reactivate years after the original infection (Kauffman 2007). Patients at particular risk for disseminated histoplasmosis include those individuals with deficient cell-mediated immunity, including infants, patients with AIDS, transplant recipients, those with hematologic malignancies, and patients undergoing treatment with corticosteroids or tumor necrosis factor antagonists (Kauffman 2007; Smith and Kauffman 2009).

The transformation of $H$. capsulatum hyphal cells to yeast cells, or vice versa, can be recapitulated in culture simply by shifting the growth temperature (Maresca and Kobayashi 1989; Maresca et al. 1994). When H. capsulatum cells are grown at room temperature, they grow in the hyphal form. When these cells are shifted to $37^{\circ} \mathrm{C}$, they shift to the budding yeast form. A number of biological assays have been applied to yeast and hyphal cells grown in the laboratory. The first $H$. capsulatum virulence factors (Cbp1 [calcium-binding protein 1] and Yps3 [yeastphase specific gene 3]) were identified by searching for high-abundance secreted factors that were produced only by yeast cells (Keath and Abidi 1994; Batanghari and Goldman 1997; Batanghari et al. 1998; Patel et al. 1998; Kugler et al. 2000a,b; Sebghati et al. 2000; Bohse and Woods 2007). Building on a robust extrachromosomal plasmid system (Woods and Goldman 1992, 1993) and electroporation technologies (Woods et al. 1998a), a combination of gene disruption (which is inefficient in $H$. capsulatum due, at least in part, to the high frequency of illegitimate recombination) (Woods et al. 1998b; Sebghati et al. 2000), Agrobacterium-mediated insertional mutagenesis (Sullivan et al. 2002; Youseff et al. 2009) and RNA interference (Rappleye et al. 2004) have been used to identify $H$. capsulatum 
factors involved in iron acquisition and homeostasis (Hilty et al. 2008, 2011; Hwang et al. 2008, 2012), intracellular parasitism (Sebghati et al. 2000; Edwards et al. 2011b; Isaac et al. 2013), cell wall $\alpha$-glucan synthesis (Rappleye et al. 2004; Marion et al. 2006; Edwards et al. 2011a), vitamin acquisition (Garfoot et al. 2014), and superoxide detoxification (Youseff et al. 2012; Holbrook et al. 2013). In addition to these molecular genetic approaches, a number of genomics and proteomics approaches have been used to determine genes whose expression is enriched in yeast or hyphae (Hwang et al. 2003; Nguyen and Sil 2008; Beyhan et al. 2013; Edwards et al. 2013), and the H. capsulatum secreted proteome (Albuquerque et al. 2008; Holbrook et al. 2011), which is presumed to include novel virulence factors. Finally, key regulatory molecules required for the temperature-dependent switch from the hyphal to yeast forms have been identified (Nemecek et al. 2006; Nguyen and Sil 2008; Webster and Sil 2008; Beyhan et al. 2013). These factors will shed light on the temperature-sensing mechanism that is key to the dimorphic switch in these organisms.

\section{Paracoccidioides brasiliensis}

P. brasiliensis is the causative agent of paracoccidioidomycosis, a disease first described in 1908 (see Goldani and Sugar 1995). It is the most common systemic mycosis in Latin America with an estimated number of infected individuals close to 10 million (Bethlem et al. 1991; Brummer et al. 1993). P. brasiliensis as a species was shown to consist of a number of distinct phylogenetic lineages that have recently been resolved into two species, P. brasiliensis and P. lutzii (Matute et al. 2006a,b). Paracoccidioides is considered a primary pathogen, infecting individuals deemed to be otherwise healthy. However, infections are most often asymptomatic, and it is believed that the fungus remains dormant in many of these instances. Disease progression is likely to be associated with some form of immunodeficiency in the host (Franco et al. 1987). A perplexing aspect of paracoccidioidomycosis is the apparent low prevalence with AIDS despite the high incidence of co- existence with HIV infection in some areas. Part of the explanation for this may relate to common prophylactic use of trimethprim-sulfamethoxazole against Pneumocystis carinii; this drug is also effective against $P$. brasiliensis. The other possibility, common to many fungal infections, is poor detection or misdiagnosis coupled with the fact that autopsies are not routinely conducted on AIDS fatalities (Goldani and Sugar 1995). Paracoccidioidomycosis is generally described as a chronic granulomatous inflammation but individual patients can exhibit a range of clinical manifestations ranging from a localized, benign disease to a disseminated, systemic mycosis. Disseminated disease is often fatal unless treated (Franco et al. 1987).

$P$. brasiliensis is endemic and restricted to South and Central America. The main environmental reservoir identified to date is in armadillos endemic to the region, but it has also been detected in a number of other mammals ( $\mathrm{Ri}$ chini-Pereira et al. 2008). The high association between Paracoccidioides and armadillos (Dasypus septemcinctus), whose body temperature is $32^{\circ} \mathrm{C}-35^{\circ} \mathrm{C}$, have a purported weak immune system and are burrowing animals, may underlie the evolution of pathogenicity in Paracoccidioides. The fungus has also been sporadically isolated from a number of other sources including bat guano and penguins (reviewed in Bagagli et al. 2008). Growth tests under various nonhost conditions show a clear preference for certain soils with high water content.

The dimorphic switch in $P$. brasiliensis is also triggered by temperature. At $25^{\circ} \mathrm{C}$, elongated hyphal cells are produced that grow apically and divide by septation. Subapical branches produce a mycelial network. Within this network of hyphal cells, asexual conidia are produced without the elaboration of a complex conidiophore structure (see Goldani and Sugar 1995). In addition, arthroconidiation has also been observed (Fig. 1) (Bagagli et al. 2008). At $37^{\circ} \mathrm{C}$, the yeast cells divide by budding but complete separation of mother and daughter cells is slow. This leads to a typical multibudded arrangement of cells (Goldani and Sugar 1995). It has been suggested that this large clump of cells is refractory to phagocytosis, and this is 
consistent with the observation that $P$. brasiliensis cells in the host are not routinely intracellular. However, it is also clear that inhaled conidia are likely to be phagocytosed by alveolar macrophages before they are able to germinate and produce these multibudded yeast forms. The transition from hyphal to yeast cells in vitro is slow, taking $10-20 \mathrm{~d}$ to fully manifest. Although a teleomorphic stage has not been described, there is suggestive evidence of a sexual cycle in some isolates (based on recombination), whereas others appear asexual (Silva et al. 2008).

Paracoccidioides infections are presumed to be initiated by inhalation of either conidia or arthroconidia and primarily occur in the lung. Some observations of Paracoccidioides inside host cells (epithelial and alveolar) have been noted, and it is thought that initial survival of the fungus within macrophages may be important for virulence (Tavares et al. 2007). Nonetheless, Paracoccidioides is not predominantly an intracellular pathogen; presumably, as mentioned above, the multibudded yeast form is too large to be readily phagocytosed by innate immune cells (Mendes-Giannini et al. 2008). As an extracellular pathogen, adherence to host cells is important. Infections can be asymptomatic or symptomatic, and in the former case the disease can become evident many years after the initial exposure, indicative a period of latency. Beyond the primary pulmonary disease, disseminated disease can also manifest, affecting the reticuloendothelial system, lymph nodes, skin, and mucosa (Goldani and Sugar 1995).

Molecular genetic tools for the manipulation of $P$. brasiliensis have been developed. The DNA-mediated transformation system is based on the Agrobacterium T-DNA transformation system developed for $H$. capsulatum using a dominant selectable marker for resistance to hygromycin (Almeida et al. 2007). The system has been coupled with antisense RNA constructs to knock down gene expression. Gene targeting has not been developed yet. Fluorescent proteins genes have been show to work in P. brasiliensis (Almeida et al. 2009). There are robust cell-based and mouse models for assessing virulence (Defaveri et al. 1982; Kerr et al. 1982;
Robledo et al. 1982). Transcriptional profiling using microarrays has been used extensively (Nunes et al. 2005; Andrade et al. 2006; Ferreira et al. 2006; Tavares et al. 2007; Monteiro et al. 2009).

\section{Sporothrix schenckii}

S. schenckii is a fungus with worldwide distribution, unlike many other dimorphic pathogens and more akin to the better known but nondimorphic Aspergillus fumigatus. S. schenckii is associated with soil and plants. Unlike the other dimorphic pathogens, S. schenckii predominantly causes cutaneous infections that initiate by minor skin trauma such as cuts and scrapes that come from handling infected material. It is often known as rose-grower's disease. Sporotrichosis was first reported in 1896 when the fungus was identified in subcutaneous abscesses (Schenck 1898). A particularly notorious outbreak of sporotrichosis occurred in South Africa where 3000 gold miners were infected by contaminated timber (cited in Lopez-Romero et al. 2011). The disease is often manifested as a chronic granulomatous infection. Like Paracoccidioides, $S$. schenckii is now considered a species complex that is comprised of six species, all of which are of medical interest, and, unless otherwise stated, a reference to $S$. schenckii is to the species complex (Lopez-Romero et al. 2011).

Despite its global distribution, certain regions like Peru appear to show much higher incidences of infection by S. schenckii (sometimes termed "hyperendemic"), probably as a consequence of higher frequencies of activities that contribute to infection (Pappas et al. 2000). Contact is also thought to be the reason why men show a much higher frequency of infection by $S$. schenckii. It is present in decaying (or not) plant material. A number of factors contribute to the development of sporotrichosis including the inoculum size and location, the host's immune state, and the virulence of the strain (Dixon et al. 1991). Generally infections are restricted to acute or chronic subcutaneous lesions but serious disseminated disease is evident with increasing numbers of immunocompromised individuals, particularly AIDS (Lopez-Romero 
et al. 2011). Infection via animals such as cats has also been documented (Barros et al. 2004).

Sporothrix differs from the other dimorphic fungi in that hyphal and yeast cells can coexist, and temperature does not appear to be a strict cue for transition between the two cell types. The hyphal cells grow by apical extension, divide by septation, and produce a number of morphologically different asexual conidia. Some conidia are oval or elongate in shape that can be produced individually or in small groups in a sympoidal manner from specialized conidiogenous cells. The other conidial cell type has a thick wall, is darkly pigmented, and is generally produced individually. This conidial type differs in shape among the Sporothrix species. Sporothrix yeast cells are oval in shape and divide by budding. Cell separation can occur with each division or it can be delayed to produce multibudded cells. These cells can be produced over a range of temperatures $\left(25^{\circ} \mathrm{C}-37^{\circ} \mathrm{C}\right)$ and generally emerge from hyphal cells at their apical tips or septation sites. There is no known sexual stage (LopezRomero et al. 2011).

For S. schenckii, unlike all the other dimorphic pathogens discussed here, the primary route of infection is not by inhalation of spores (although there is evidence of this possibility) but instead by the hyphal form on inoculation through superficial wounding. Infections are usually localized to the skin resulting in an ulcerated nodule and sometimes spread to the lymphatic system. In immunocompromised individuals such as those with AIDS, serious disseminated disease is common and can affect many parts of the body including the bones, joints, and the central nervous system (LopezRomero et al. 2011).

There is a paucity of molecular genetic tools available for Sporothrix. A DNA-mediated transformation system utilizing Agrobacterium T-DNA-mediated insertion was developed based on that described for T. marneffei and Aspergillus awamori and was used for an insertional mutagenesis screen (Zhang et al. 2011). Gene targeting has not been developed yet. Pulse-field gel electrophoresis has been used to examine chromosomal polymorphism in isolates (Sasaki et al. 2014). There are robust cell- based and mouse models for assessing virulence (Hachisuka and Sasai 1981; Kennedy et al. 1982; Dickerson et al. 1983).

\section{Talaromyces marneffei}

Penicillium marneffei, recently renamed T. marneffei on the basis of new sequence data that has seen a division of the classically defined Penicillium group of fungi (Samson et al. 2011), was originally identified in 1956 from a bamboo rat in Vietnam (Segretain 1959). Despite its coexistence with rats in the endemic region, it has rarely been isolated from the environment, suggesting that the reservoir may in fact be the rat. The first documented human infection was by an accidental needle stick of a researcher (DiSalvo et al. 1973). It has risen to prominence as a significant human pathogen across Southeast Asia with the global AIDS pandemic (Vanittanakom et al. 2006). The disease penicilliosis marneffei occurs predominantly in immunocompromised individuals and initiates as a pulmonary infection followed by hematogenous dissemination to a systemic mycosis (Cheng et al. 1998; Rimek et al. 1999; Garbino et al. 2001). As such, it is considered an opportunistic pathogen; however, systemic disease is fatal if untreated. A small number of cases of infection in "immunocompetent" individuals have been described, but it should be noted that in none of these cases has immune status been adequately tested, and "immunocompetency" is often used interchangeably (and incorrectly) with HIVnegative status. The British novelist and travel writer Bruce Chatwin (1963-1989) was diagnosed with penicilliosis marneffei (Shakespeare and Neely 2011).

T. marneffei is endemic to Southeast Asia and as a consequence of its escalating incidence represents an "AIDS-defining pathogen" in this region (Supparatpinyo et al. 1994; Ustianowski et al. 2008). The increasing frequency of travel to Asia and the capacity of T. marneffei to exist without a host has seen a spread of incidents across Asia and confirmed cases in Europe, North America, Africa, and Australia have been documented (Vanittanakom et al. 2006). Despite its prototrophy and ability to grow on a 
wide range of nutrient sources, suggestive of a saprophytic lifestyle in the hyphal form, T. marneffei is almost always associated with bamboo rats in the environment (for review, see Vanittanakom et al. 2006). Part of the reason for this may lie in the fact that it is relatively slow growing and may not compete well with other microbes in the soil (Vanittanakom et al. 1995; Joshi et al. 2003). The bamboo rat as an environmental niche may have contributed to the evolution of its pathogenic potential and it is unclear whether the yeast growth form is found outside mammalian hosts. Population genetic studies of isolates from bamboo rats and humans across Asia suggest a highly clonal structure but with clear signs of recombination. These populations appear spatially restricted and overlap with characterized bamboo rat distributions. Coupled with data from experiments in mice, it appears that recombination may be occurring within hosts, and, if this is a requirement, it may represent population barriers for T. marneffei (Henk et al. 2012). There is no evidence that T. marneffei infections in humans are derived zoonotically and it is generally accepted that, like many other fungi, infection is initiated by inhalation of dormant conidia. In support of this are data linking infections with agricultural occupation and increased incidence during the rainy season, at least in Northern Thailand (Chariyalertsak et al. 1996).

Like the other important dimorphic fungal pathogens, T. marneffei exhibits dimorphic growth producing two distinct cellular forms, unicellular yeast and multicellular hyphae, under specific environmental conditions (Andrianopoulos 2002). T. marneffei is the only known Talaromyces (Penicillium) species that is dimorphic or a human pathogen, suggesting that these are linked emergent traits. The switch between growth forms is regulated by temperature (Andrianopoulos 2002). At $25^{\circ} \mathrm{C}$, T. marneffei grows as multinucleate, septate, branched hyphae. These hyphae produce conidia, the infectious agent, from specialized multicellular structures termed conidiophores. When switched to $37^{\circ} \mathrm{C}$, T. marneffei undergoes a morphogenetic process termed arthroconidiation. Cellular and nuclear division become coupled, double septa are laid down, and hyphae fragment at these septation sites to liberate uninucleate yeast cells that divide by fission (Andrianopoulos 2002). The yeast cells are the pathogenic form and are found in the pulmonary alveolar macrophages and peripheral blood mononuclear cells of infected individuals (Vanittanakom et al. 2006). In contrast to the hyphal-yeast dimorphic transition in vitro, conidia that are phagocytosed by macrophages germinate directly into yeast cells, bypassing the arthroconidiation process. Intracellular yeast cells are morphologically similar to those of other intracellular fungal pathogens such as $H$. capsulatum but can be distinguished at division because T. marneffei yeast cells divide by fission (Ignatov and Keath 2002).

T. marneffei infection is likely to occur through inhalation of the conidia, which are phagocytosed by host pulmonary alveolar macrophages (Vanittanakom et al. 2006). How T. marneffei is able to survive in the stressful intracellular environment of the phagocytic macrophage is not completely clear. Conidia phagocytosed by alveolar macrophages germinate inside these host cells into the pathogenic yeast form and proliferate. This leads to a pulmonary infection that disseminates haemotogenously to the lymphatic system, liver, spleen, and bones (Kudeken et al. 1996). Skin lesions are often evident occurring mostly on the face and neck. Untreated disseminated disease is often fatal. Experiments in mice have shown that, in the absence of immunosuppression, infections with high numbers of conidia $\left(4 \times 10^{5}\right)$ are eventually cleared, whereas athymic mice die from the infection (Kudeken et al. 1997). This shows that immune status of the host is a key factor in the outcome of infection.

An extensive set of molecular genetic tools has been developed for T. marneffei using the type strain (FRR2161/ATCC18224). These tools have been used to probe the molecular mechanisms that control the dimorphic switch and allow the fungus to survive within the host. These include (1) a very high frequency DNA-mediated transformation procedure using PEG-based protoplast fusions that results in integration of exogenous DNA (Borneman et al. 2001), (2) a collection of nutritional and 
dominant selectable markers with matching recipient strains for transformation (Boyce et al. 2012), (3) enhanced strains in which DNA integration is strictly by homologous recombination using mutants in the nonhomologous endjoining (NHEJ) system (Bugeja et al. 2012), (4) strains expressing fluorescent proteins for livecell tracking (Boyce et al. 2012), (5) antisense RNA knockdown systems (Canovas et al. 2011), (6) gateway systems for rapid construct generation (Boyce et al. 2012; Bugeja et al. 2012), (7) promoters for controlled expression of genes (Borneman et al. 2000; Boyce et al. 2001), (8) genomic and transcriptomic technologies (Pasricha et al. 2013), and (9) cell culture, zebrafish, and mouse-based systems for virulence testing (Boyce and Andrianopoulos 2007; Ellett et al. 2011; Henk et al. 2012). A procedure for DNAmediated transformation using the Agrobacterium transfer-DNA system has also been described (Kummasook et al. 2010).

\section{CONCLUSION}

The thermally dimorphic fungi are a captivating group of organisms that use a myriad of strategies to manipulate the progression of disease in the host. The evolutionary link between dimorphism and virulence is a subject of great interest for microbiologists, and the advent of robust molecular approaches and next-generation sequencing make it a propitious time to explore the pathogenesis and basic biology of these fascinating organisms.

\section{REFERENCES}

Abuodeh RO, Orbach MJ, Mandel MA, Das A, Galgiani JN 2000. Genetic transformation of Coccidioides immitis facilitated by Agrobacterium tumefaciens. J Infect Dis 181: 2106-2110.

Albuquerque PC, Nakayasu ES, Rodrigues ML, Frases S, Casadevall A, Zancope-Oliveira RM, Almeida IC, Nosanchuk JD. 2008. Vesicular transport in Histoplasma capsulatum: An effective mechanism for trans-cell wall transfer of proteins and lipids in ascomycetes. Cell Microbiol 10: 1695-1710.

Almeida AJ, Carmona JA, Cunha C, Carvalho A, Rappleye CA, Goldman WE, Hooykaas PJ, Leao C, Ludovico P, Rodrigues F. 2007. Towards a molecular genetic system for the pathogenic fungus Paracoccidioides brasiliensis. Fungal Genet Biol 44: 1387-1398.
Almeida AJ, Cunha C, Carmona JA, Sampaio-Marques B, Carvalho A, Malavazi I, Steensma HY, Johnson DI, Leao C, Logarinho E, et al. 2009. Cdc42p controls yeast-cell shape and virulence of Paracoccidioides brasiliensis. Fungal Genet Biol 46: 919-926.

Andrade RV, Paes HC, Nicola AM, de Carvalho MJ, Fachin AL, Cardoso RS, Silva SS, Fernandes L, Silva SP, Donadi EA, et al. 2006. Cell organisation, sulphur metabolism and ion transport-related genes are differentially expressed in Paracoccidioides brasiliensis mycelium and yeast cells. BMC Genomics 7: 208.

Andrianopoulos A. 2002. Control of morphogenesis in the human fungal pathogen Penicillium marneffei. Int $\mathrm{J} \mathrm{Med}$ Microbiol 292: 331-347.

Arnett MV, Fraser SL, Grbach VX. 2008. Pulmonary blastomycosis diagnosed in Hawai'i. Southeast Asian J Trop Med Public Health 39: 701-705.

Ashburn LL, Emmons CW. 1942. Spontaneous coccidioidal granuloma in the lungs of wild rodents. Arch Pathol 34: 791-800.

Bagagli E, Theodoro RC, Bosco SM, McEwen JG. 2008. Paracoccidioides brasiliensis: Phylogenetic and ecological aspects. Mycopathologia 165: 197-207.

Barros MB, Schubach Ade O, do Valle AC, Gutierrez Galhardo MC, Conceicao-Silva F, Schubach TM, Reis RS, Wanke B, Marzochi KB, Conceicao MJ. 2004. Cat-transmitted sporotrichosis epidemic in Rio de Janeiro, Brazil: Description of a series of cases. Clin Infect Dis 38: 529535.

Batanghari JW, Goldman WE. 1997. Calcium dependence and binding in cultures of Histoplasma capsulatum. Infect Immun 65: 5257-5261.

Batanghari JW, Deepe GS Jr, Di Cera E, Goldman WE. 1998. Histoplasma acquisition of calcium and expression of CBP1 during intracellular parasitism. Mol Microbiol 27: 531-539.

Baumgardner DJ, Paretsky DP, Yopp AC. 1995. The epidemiology of blastomycosis in dogs: North central Wisconsin, USA. J Med Vet Mycol 33: 171-176.

Bethlem NM, Lemle A, Bethlem E, Wanke B. 1991. Paracoccidioidomycosis. Semin Respir Med 12: 81-86.

Beyhan S, Gutierrez M, Voorhies M, Sil A. 2013. A temperature-responsive network links cell shape and virulence traits in a primary fungal pathogen. PLoS Biol 11: e1001614.

Bohse ML, Woods JP. 2007. RNA interference-mediated silencing of the YPS3 gene of Histoplasma capsulatum reveals virulence defects. Infect Immun 75: 2811-2817.

Borneman AR, Hynes MJ, Andrianopoulos A. 2000. The abaA homologue of Penicillium marneffei participates in two developmental programmes: Conidiation and dimorphic growth. Mol Microbiol 38: 1034-1047.

Borneman AR, Hynes MJ, Andrianopoulos A. 2001. An STE12 homolog from the asexual, dimorphic fungus Penicillium marneffei complements the defect in sexual development of an Aspergillus nidulans steA mutant. Genetics 157: 1003-1014.

Boyce KJ, Andrianopoulos A. 2007. A p21-activated kinase is required for conidial germination in Penicillium marneffei. PLoS Pathog 3: e162. 
Boyce KJ, Hynes MJ, Andrianopoulos A. 2001. The CDC42 homolog of the dimorphic fungus Penicillium marneffei is required for correct cell polarization during growth but not development. J Bacteriol 183: 3447-3457.

Boyce KJ, Bugeja HE, Weerasinghe H, Payne M, Schreider L, Park C, Woodward T, Andrianopoulos A. 2012. Strategies for the molecular genetic manipulation and visualization of the human fungal pathogen Penicillium marneffei. Fungal Genet Rep 59: 1-12.

Brandhorst TT, Rooney PJ, Sullivan TD, Klein BS. 2002. Using new genetic tools to study the pathogenesis of Blastomyces dermatitidis. Trends Microbiol 10: 25-30.

Brodsky AL, Gregg MB, Loewenstein MS, Kaufman L, Mallison GF. 1973. Outbreak of histoplasmosis associated with the 1970 Earth Day activities. Am J Med 54: 333342 .

Brown GD, Denning DW, Gow NA, Levitz SM, Netea MG, White TC. 2012. Hidden killers: Human fungal infections. Sci Transl Med 4: 165rv113.

Brummer E, Castaneda E, Restrepo A. 1993. Paracoccidioidomycosis: An update. Clin Microbiol Rev 6: 89-117.

Bugeja HE, Boyce KJ, Weerasinghe H, Beard S, Jeziorowski A, Pasricha S, Payne M, Schreider L, Andrianopoulos A. 2012. Tools for high efficiency genetic manipulation of the human pathogen Penicillium marneffei. Fungal Genet Biol 49: 772-778.

Bullock WE. 1993. Interactions between human phagocytic cells and Histoplasma capsulatum. Arch Med Res 24: 219 223.

Cano MV, Ponce-de-Leon GF, Tippen S, Lindsley MD, Warwick M, Hajjeh RA. 2003. Blastomycosis in Missouri Epidemiology and risk factors for endemic disease. Epidemiol Infect 131: 907-914.

Canovas D, Boyce KJ, Andrianopoulos A. 2011. The fungal type II myosin in Penicillium marneffei, MyoB, is essential for chitin deposition at nascent septation sites but not actin localization. Eukaryot Cell 10: 302-312.

Chariyalertsak S, Sirisanthana T, Supparatpinyo K, Nelson KE. 1996. Seasonal variation of disseminated Penicillium marneffei infections in northern Thailand: A clue to the reservoir? J Infect Dis 173: 1490-1493.

Cheng NC, Wong WW, Fung CP, Liu CY. 1998. Unusual pulmonary manifestations of disseminated Penicillium marneffei infection in three AIDS patients. Med Mycol 36: $429-432$.

Chiller TM, Galgiani JN, Stevens DA. 2003. Coccidioidomycosis. Infect Dis Clin North Am 17: 41-57.

Chu JH, Feudtner C, Heydon K, Walsh TJ, Zaoutis TE. 2006. Hospitalizations for endemic mycoses: A populationbased national study. Clin Infect Dis 42: 822-825.

Cockshott WP, Lucas AO. 1964. Histoplasmosis duboisii. QJ Med 33: 223-238.

Converse JL. 1955. Growth of spherules of Coccidioides immitis in a chemically defined liquid medium. Proc Soc Exp Biol Med 90: 709-711.

Crampton TL, Light RB, Berg GM, Meyers MP, Schroeder GC, Hershfield ES, Embil JM. 2002. Epidemiology and clinical spectrum of blastomycosis diagnosed at Manitoba hospitals. Clin Infect Dis 34: 1310-1316.
Darling ST. 1906. A protozoan general infection producing pseudotubercles in the lungs and focal necroses in the liver, spleen, and lymph nodes. JAMA 46: 1283-1285.

Deepe GS Jr. 2000. Immune response to early and late Histoplasma capsulatum infections. Curr Opin Microbiol 3: 359-362.

Defaveri J, Rezkallah-Iwasso MT, de Franco MF. 1982. Experimental pulmonary paracoccidioidomycosis in mice: Morphology and correlation of lesions with humoral and cellular immune response. Mycopathologia 77: 3-11.

De Groote MA, Bjerke R, Smith H, Rhodes IL. 2000. Expanding epidemiology of blastomycosis: Clinical features and investigation of 2 cases in Colorado. Clin Infect Dis 30: $582-584$.

Dickerson CL, Taylor RL, Drutz DJ. 1983. Susceptibility of congenitally athymic (nude) mice to sporotrichosis. Infect Immun 40: 417-420.

Dickson EC. 1915. Oidomycosis in California with especial reference to coccidioidal granuloma, including nine new cases of coccidioidal granuloma. Arch Internal Med 15: 479-486.

DiSalvo AF, Fickling AM, Ajello L. 1973. Infection caused by Penicillium marneffei: Description of first natural infection in man. Am J Clin Pathol 60: 259-263.

Dixon DM, Salkin IF, Duncan RA, Hurd NJ, Haines JH, Kemna ME, Coles FB. 1991. Isolation and characterization of Sporothrix schenckii from clinical and environmental sources associated with the largest U.S. epidemic of sporotrichosis. J Clin Microbiol 29: 1106-1113.

Dworkin MS, Duckro AN, Proia L, Semel JD, Huhn G. 2005. The epidemiology of blastomycosis in Illinois and factors associated with death. Clin Infect Dis 41: e107-e111.

Edwards JA, Alore EA, Rappleye CA. 2011a. The yeast-phase virulence requirement for $\alpha$-glucan synthase differs among Histoplasma capsulatum chemotypes. Eukaryot Cell 10: 87-97.

Edwards JA, Zemska O, Rappleye CA. 2011b. Discovery of a role for Hsp82 in Histoplasma virulence through a quantitative screen for macrophage lethality. Infect Immun 79: 3348-3357.

Edwards JA, Chen C, Kemski MM, Hu J, Mitchell TK, Rappleye CA. 2013. Histoplasma yeast and mycelial transcriptomes reveal pathogenic-phase and lineage-specific gene expression profiles. BMC Genomics 14: 695.

Eissenberg LG, Goldman WE. 1991. Histoplasma variation and adaptive strategies for parasitism: new perspectives on histoplasmosis. Clin Microbiol Rev 4: 411-421.

Ellett F, Pase L, Hayman JW, Andrianopoulos A, Lieschke GJ. 2011. mpeg1 promoter transgenes direct macrophagelineage expression in zebrafish. Blood 117: e49-e56.

Emmons CW. 1949. Isolation of Histoplasma capsulatum from soil. Public Health Rep 64: 892-896.

Emmons CW. 1962. Soil reservoirs of pathogenic fungi. J Wash Acad Sci 52: 3-9.

Ferreira ME, Marques Edos R, Malavazi I, Torres I, Restrepo A, Nunes LR, de Oliveira RC, Goldman MH, Goldman GH. 2006. Transcriptome analysis and molecular studies on sulfur metabolism in the human pathogenic fungus Paracoccidioides brasiliensis. Mol Genet Genomics 276: 450-463. 
Fisher MC, Koenig GL, White TJ, Taylor JW. 2002. Molecular and phenotypic description of Coccidioides posadasii sp. nov., previously recognized as the non-California population of Coccidioides immitis. Mycologia 94: 73-84.

Franco M, Montenegro MR, Mendes RP, Marques SA, Dillon NL, Mota NG. 1987. Paracoccidioidomycosis: A recently proposed classification of its clinical forms. Rev Soc Bras Med Trop 20: 129-132.

Galgiani JN, Ampel NM, Blair JE, Catanzaro A, Johnson RH, Stevens DA, Williams PL. 2005. Coccidioidomycosis. Clin Infect Dis 41: 1217-1223.

Garbino J, Kolarova L, Lew D, Hirschel B, Rohner P. 2001. Fungemia in HIV-infected patients: A 12-year study in a tertiary care hospital. AIDS Patient Care STDs 15: 407 410.

Garfoot AL, Zemska O, Rappleye CA. 2014. Histoplasma capsulatum depends on de novo vitamin biosynthesis for intraphagosomal proliferation. Infect Immun 82: 393-404.

Gauthier GM, Sullivan TD, Gallardo SS, Brandhorst TT, Vanden Wymelenberg AJ, Cuomo CA, Suen G, Currie CR, Klein BS. 2010. SREB, a GATA transcription factor that directs disparate fates in Blastomyces dermatitidis including morphogenesis and siderophore biosynthesis. PLoS Pathog 6: e1000846.

Gilchrist TC. 1894. Protazoan dermatitidis. J Cutan Genitourin Dis 12: 496-499.

Gilchrist TC, Stokes WR. 1896. The presence of an Oidium in the tissues of a case of pseudolupus vulgaris. Bull Johns Hopkins Hosp 7: 129-133.

Gilchrist TC, Stokes WR. 1898. A case of pseudolupus caused by Blastomyces. J Exp Med 3: 53-78.

Goldani LZ, Sugar AM. 1995. Paracoccidioidomycosis and AIDS: An overview. Clin Infect Dis 21: 1275-1281.

Hachisuka H, Sasai Y. 1981. Development of experimental sporotrichosis in normal and modified animals. Mycopathologia 76: 79-82.

Hector RF, Rutherford GW, Tsang CA, Erhart LM, McCotter O, Anderson SM, Komatsu K, Tabnak F, Vugia DJ, Yang Y, et al. 2011. The public health impact of coccidioidomycosis in Arizona and California. Int J Environ Res Public Health 8: 1150-1173.

Henk DA, Shahar-Golan R, Devi KR, Boyce KJ, Zhan N, Fedorova ND, Nierman WC, Hsueh PR, Yuen KY, Sieu TP, et al. 2012. Clonality despite sex: The evolution of host-associated sexual neighborhoods in the pathogenic fungus Penicillium marneffei. PLoS Pathog 8: e1002851.

Hilty J, Smulian AG, Newman SL. 2008. The Histoplasma capsulatum vacuolar ATPase is required for iron homeostasis, intracellular replication in macrophages and virulence in a murine model of histoplasmosis. Mol Microbiol 70: $127-139$.

Hilty J, George Smulian A, Newman SL. 2011. Histoplasma capsulatum utilizes siderophores for intracellular iron acquisition in macrophages. Med Mycol 49: 633-642.

Hoff GL, Bigler WJ. 1981. The role of bats in the propagation and spread of histoplasmosis: A review. J Wildl Dis 17: 191-196.

Holbrook ED, Edwards JA, Youseff BH, Rappleye CA. 2011. Definition of the extracellular proteome of pathogenic- phase Histoplasma capsulatum. J Proteome Res 10: 19291943.

Holbrook ED, Smolnycki KA, Youseff BH, Rappleye CA. 2013. Redundant catalases detoxify phagocyte reactive oxygen and facilitate Histoplasma capsulatum pathogenesis. Infect Immun 81: 2334-2346.

Huffnagle GB, Deepe GS. 2003. Innate and adaptive determinants of host susceptibility to medically important fungi. Curr Opin Microbiol 6: 344-350.

Hung CY, Xue J, Cole GT. 2007. Virulence mechanisms of coccidioides. Ann NY Acad Sci 1111: 225-235.

Hung CY, Wise HZ, Cole GT. 2012. Gene disruption in Coccidioides using hygromycin or phleomycin resistance markers. Methods Mol Biol 845: 131-147.

Hwang L, Hocking-Murray D, Bahrami AK, Andersson M, Rine J, Sil A. 2003. Identifying phase-specific genes in the fungal pathogen Histoplasma capsulatum using a genomic shotgun microarray. Mol Biol Cell 14: 2314-2326.

Hwang LH, Mayfield JA, Rine J, Sil A. 2008. Histoplasma requires SID1, a member of an iron-regulated siderophore gene cluster, for host colonization. PLoS Pathog 4: e1000044.

Hwang LH, Seth E, Gilmore SA, Sil A. 2012. SRE1 regulates iron-dependent and -independent pathways in the fungal pathogen Histoplasma capsulatum. Eukaryot Cell 11: 1625.

Ignatov A, Keath EJ. 2002. Molecular cell biology and molecular genetics of Histoplasma capsulatum. Int J Med Microbiol 292: 349-361.

Isaac DT, Coady A, Van Prooyen N, Sil A. 2013. The 3hydroxy-methylglutaryl coenzyme A lyase HCL1 is required for macrophage colonization by human fungal pathogen Histoplasma capsulatum. Infect Immun 81: 411-420.

Johannesson H, Kasuga T, Schaller RA, Good B, Gardner MJ, Townsend JP, Cole GT, Taylor JW. 2006. Phase-specific gene expression underlying morphological adaptations of the dimorphic human pathogenic fungus, Coccidioides posadasii. Fungal Genet Biol 43: 545-559.

Joshi A, Gugnani HG, Vijayan VK. 2003. Survival of Penicillium marneffei in sterile and unsterile soil. J Mycol Med 13: $211-212$.

Kasuga T, White TJ, Koenig G, McEwen J, Restrepo A, Castaneda E, Da Silva Lacaz C, Heins-Vaccari EM, De Freitas RS, Zancope-Oliveira RM, et al. 2003. Phylogeography of the fungal pathogen Histoplasma capsulatum. Mol Ecol 12: $3383-3401$.

Kauffman CA. 2007. Histoplasmosis: A clinical and laboratory update. Clin Microbiol Rev 20: 115-132.

Keath EJ, Abidi FE. 1994. Molecular cloning and sequence analysis of $y p s-3$, a yeast-phase-specific gene in the $\mathrm{di}$ morphic fungal pathogen Histoplasma capsulatum. Microbiology 140: 759-767.

Kennedy MJ, Bajwa PS, Volz PA. 1982. Gastrointestinal inoculation of Sporothrix schenckii in mice. Mycopathologia 78: $141-143$.

Kerr IB, da Costa SC, Alencar A. 1982. Experimental paracoccidioidomycosis in immunosuppressed mice. Immunol Lett 5: 151-154.

Kirkland TN, Fierer J. 1996. Coccidioidomycosis: A reemerging infectious disease. Emerg Infect Dis 2: 192-199. 
Klein BS, Vergeront JM, Davis JP. 1986. Epidemiologic aspects of blastomycosis, the enigmatic systemic mycosis Semin Respir Infect 1: 29-39.

Klein BS, Vergeront JM, DiSalvo AF, Kaufman L, Davis JP. 1987. Two outbreaks of blastomycosis along rivers in Wisconsin. Isolation of Blastomyces dermatitidis from riverbank soil and evidence of its transmission along waterways. Am Rev Respir Dis 136: 1333-1338.

Krajaejun T, Gauthier GM, Rappleye CA, Sullivan TD, Klein BS. 2007. Development and application of a green fluorescent protein sentinel system for identification of RNA interference in Blastomyces dermatitidis illuminates the role of septin in morphogenesis and sporulation. Eukaryot Cell 6: 1299-1309.

Kudeken N, Kawakami K, Kusano N, Saito A. 1996. Cellmediated immunity in host resistance against infection caused by Penicillium marneffei. J Med Vet Mycol 34: 371-378.

Kudeken N, Kawakami K, Saito A. 1997. CD4 ${ }^{+}$T cell-mediated fatal hyperinflammatory reactions in mice infected with Penicillium marneffei. Clin Exp Immunol 107: $468-473$.

Kugler S, Schurtz Sebghati T, Groppe Eissenberg L, Goldman WE. 2000a. Phenotypic variation and intracellular parasitism by Histoplasma capsulatum. Proc Natl Acad Sci 97: 8794-8798.

Kugler S, Young B, Miller VL, Goldman WE. 2000b. Monitoring phase-specific gene expression in Histoplasma capsulatum with telomeric GFP fusion plasmids. Cell Microbiol 2: 537-547.

Kummasook A, Cooper CR Jr, Vanittanakom N. 2010. An improved Agrobacterium-mediated transformation system for the functional genetic analysis of Penicillium marneffei. Med Mycol 48: 1066-1074.

Larkin MA, Blackshields G, Brown NP, Chenna R, McGettigan PA, McWilliam H, Valentin F, Wallace IM, Wilm A, Lopez R, et al. 2007. Clustal W and Clustal X version 2.0. Bioinformatics 23: 2947-2948.

Lopez-Romero E, Reyes-Montes Mdel R, Perez-Torres A, Ruiz-Baca E, Villagomez-Castro JC, Mora-Montes HM Flores-Carreon A, Toriello C. 2011. Sporothrix schenckii complex and sporotrichosis, an emerging health problem. Future Microbiol 6: 85-102.

Maresca B, Kobayashi GS. 1989. Dimorphism in Histoplasma capsulatum: A model for the study of cell differentiation in pathogenic fungi. Microbiol Rev 53: 186209.

Maresca B, Kobayashi GS. 2000. Dimorphism in Histoplasma capsulatum and Blastomyces dermatitidis. Contrib Microbiol 5: 201-216.

Maresca B, Carratu L, Kobayashi GS. 1994. Morphological transition in the human fungal pathogen Histoplasma capsulatum. Trends Microbiol 2: 110-114.

Marion CL, Rappleye CA, Engle JT, Goldman WE. 2006. An $\alpha$-(1,4)-amylase is essential for $\alpha$-(1,3)-glucan production and virulence in Histoplasma capsulatum. Mol Microbiol 62: 970-983.

Marsden-Haug N, Goldoft M, Ralston C, Limaye AP, Chua J, Hill H, Jecha L, Thompson GR III, Chiller T. 2013. Coccidioidomycosis acquired in Washington State. Clin Infect Dis 56: 847-850.
Thermally Dimorphic Human Fungal Pathogens

Matute DR, McEwen JG, Puccia R, Montes BA, San-Blas G, Bagagli E, Rauscher JT, Restrepo A, Morais F, Nino-Vega $\mathrm{G}$, et al. 2006a. Cryptic speciation and recombination in the fungus Paracoccidioides brasiliensis as revealed by gene genealogies. Mol Biol Evol 23: 65-73.

Matute DR, Sepulveda VE, Quesada LM, Goldman GH, Taylor JW, Restrepo A, McEwen JG. 2006b. Microsatellite analysis of three phylogenetic species of Paracoccidioides brasiliensis. J Clin Microbiol 44: 2153-2157.

Mendes-Giannini MJ, Monteiro da Silva JL, de Fatima da Silva J, Donofrio FC, Miranda ET, Andreotti PF, Soares CP. 2008. Interactions of Paracoccidioides brasiliensis with host cells: Recent advances. Mycopathologia 165: $237-$ 248.

Monteiro JP, Clemons KV, Mirels LF, Coller JA Jr, Wu TD, Shankar J, Lopes CR, Stevens DA. 2009. Genomic DNA microarray comparison of gene expression patterns in Paracoccidioides brasiliensis mycelia and yeasts in vitro. Microbiology 155: 2795-2808.

Neafsey DE, Barker BM, Sharpton TJ, Stajich JE, Park DJ, Whiston E, Hung CY, McMahan C, White J, Sykes S, et al. 2010. Population genomic sequencing of Coccidioides fungi reveals recent hybridization and transposon control. Genome Res 20: 938-946.

Nemecek JC, Wuthrich M, Klein BS. 2006. Global control of dimorphism and virulence in fungi. Science 312: $583-$ 588.

Newman SL. 1999. Macrophages in host defense against Histoplasma capsulatum. Trends Microbiol 7: 67-71.

Nguyen VQ, Sil A. 2008. Temperature-induced switch to the pathogenic yeast form of Histoplasma capsulatum requires Ryp1, a conserved transcriptional regulator. Proc Natl Acad Sci 105: 4880-4885.

Nguyen C, Barker BM, Hoover S, Nix DE, Ampel NM, Frelinger JA, Orbach MJ, Galgiani JN. 2013. Recent advances in our understanding of the environmental, epidemiological, immunological, and clinical dimensions of coccidioidomycosis. Clin Microbiol Rev 26: 505-525.

Nunes LR, Costa de Oliveira R, Leite DB, da Silva VS, dos Reis Marques E, da Silva Ferreira ME, Ribeiro DC, de Souza Bernardes LA, Goldman MH, Puccia R, et al. 2005. Transcriptome analysis of Paracoccidioides brasiliensis cells undergoing mycelium-to-yeast transition. Eukaryot Cell 4: 2115-2128.

Ophuls W, Moffitt HC. 1900. A new pathogenic mould (formerly described as a protozoon: Coccidioides immitis pyogenes): Preliminary report. Philadelphia Med J 5: $1471-1472$.

Pappagianis D. 1988. Epidemiology of coccidioidomycosis. Curr Top Med Mycol 2: 199-238.

Pappagianis D, Lindsay S, Beall S, Williams P. 1979. Ethnic background and the clinical course of coccidioidomycosis. Am Rev Respir Dis 120: 959-961.

Pappas PG, Tellez I, Deep AE, Nolasco D, Holgado W, Bustamante B. 2000. Sporotrichosis in Peru: Description of an area of hyperendemicity. Clin Infect Dis 30: 65-70.

Pasricha S, Payne M, Canovas D, Pase L, Ngaosuwankul N, Beard S, Oshlack A, Smyth GK, Chaiyaroj SC, Boyce KJ, et al. 2013. Cell-type-specific transcriptional profiles of the dimorphic pathogen Penicillium marneffei reflect distinct reproductive, morphological, and environmental demands. G3 (Bethesda) 3: 1997-2014. 
Patel JB, Batanghari JW, Goldman WE. 1998. Probing the yeast phase-specific expression of the CBP1 gene in Histoplasma capsulatum. J Bacteriol 180: 1786-1792.

Pfaller MA, Diekema DJ. 2010. Epidemiology of invasive mycoses in North America. Crit Rev Microbiol 36: 1-53.

Pine L. 1960. Morphological and physiological characteristics of Histoplasma capsulatum. Charles C Thomas, Springfield, IL.

Posadas A. 1892. Un nuevo caso de micosis fungiodea con psorospermias [A new case of mycosis fungoides with psorospermias]. Ann Circ Med Argent 15: 585-597.

Rappleye CA, Engle JT, Goldman WE. 2004. RNA interference in Histoplasma capsulatum demonstrates a role for $\alpha$-(1,3)-glucan in virulence. Mol Microbiol 53: 153-165.

Richini-Pereira VB, Bosco Sde M, Griese J, Theodoro RC, Macoris SA, da Silva RJ, Barrozo L, Tavares PM, ZancopeOliveira RM, Bagagli E. 2008. Molecular detection of Paracoccidioides brasiliensis in road-killed wild animals. Med Mycol 46: 35-40.

Rimek D, Zimmermann T, Hartmann M, Prariyachatigul C, Kappe R. 1999. Disseminated Penicillium marneffei infection in an HIV-positive female from Thailand in Germany. Mycoses 42: 25-28.

Rixford E. 1894. A case of protazoan dermatitis. In Occidental medical times, Vol. 8. D. Johnston, Sacramento, CA.

Robledo MA, Graybill JR, Ahrens J, Restrepo A, Drutz DJ, Robledo M. 1982. Host defense against experimental paracoccidioidomycosis. Am Rev Respir Dis 125: 563567.

Samson RA, Yilmaz N, Houbraken J, Spierenburg H, Seifert KA, Peterson SW, Varga J, Frisvad JC. 2011. Phylogeny and nomenclature of the genus Talaromyces and taxa accommodated in Penicillium subgenus Biverticillium. Stud Mycol 70: 159-183.

Sasaki AA, Fernandes GF, Rodrigues AM, Lima FM, Marini MM, Dos SFL, de Melo Teixeira M, Felipe MS, da Silveira JF, de Camargo ZP. 2014. Chromosomal polymorphism in the Sporothrix schenckii complex. PLoS ONE 9: e86819.

Schenck B. 1898. On refractory subcutaneous abscesses caused by a fungus possibly related to sporotrichia. John Hopkins Hosp Bull 9: 286-290.

Sebghati TS, Engle JT, Goldman WE. 2000. Intracellular parasitism by Histoplasma capsulatum: Fungal virulence and calcium dependence. Science 290: 1368-1372.

Segretain G. 1959. Penicillium marneffei n.sp., agent of a mycosis of the reticuloendothelial system. Mycopathologia 11: 327-353.

Shakespeare N, Neely M. 2011. Catalogue of papers of (Charles) Bruce Chatwin, 1963-89. Bodleian Library, University of Oxford, Oxford, UK.

Sharpton TJ, Stajich JE, Rounsley SD, Gardner MJ, Wortman JR, Jordar VS, Maiti R, Kodira CD, Neafsey DE, Zeng Q, et al. 2009. Comparative genomic analyses of the human fungal pathogens Coccidioides and their relatives. Genome Res 19: 1722-1731.

Silva SS, Paes HC, Soares CM, Fernandes L, Felipe MS. 2008. Insights into the pathobiology of Paracoccidioides brasiliensis from transcriptome analysis-Advances and perspectives. Mycopathologia 165: 249-258.
Smith JA, Kauffman CA. 2009. Endemic fungal infections in patients receiving tumour necrosis factor- $\alpha$ inhibitor therapy. Drugs 69: 1403-1415.

Smith JA, Kauffman CA. 2010. Blastomycosis. Proc Am Thorac Soc 7: 173-180.

Steenbergen JN, Nosanchuk JD, Malliaris SD, Casadevall A. 2004. Interaction of Blastomyces dermatitidis, Sporothrix schenckii, and Histoplasma capsulatum with Acanthamoeba castellanii. Infect Immun 72: 3478-3488.

Sullivan TD, Rooney PJ, Klein BS. 2002. Agrobacterium tumefaciens integrates transfer DNA into single chromosomal sites of dimorphic fungi and yields homokaryotic progeny from multinucleate yeast. Eukaryot Cell 1: 895905.

Sun SH, Huppert M, Vukovich KR. 1976. Rapid in vitro conversion and identification of Coccidioides immitis. J Clin Microbiol 3: 186-190.

Supparatpinyo K, Khamwan C, Baosoung V, Nelson KE, Sirisanthana T. 1994. Disseminated Penicillium marneffei infection in Southeast Asia. Lancet 344: 110-113.

Tavares AH, Silva SS, Dantas A, Campos EG, Andrade RV, Maranhao AQ, Brigido MM, Passos-Silva DG, Fachin AL, Teixeira SM, et al. 2007. Early transcriptional response of Paracoccidioides brasiliensis upon internalization by murine macrophages. Microbes Infect 9: 583-590.

Ustianowski AP, Sieu TPM, Day JN. 2008. Penicillium marneffei infection in HIV. Curr Opin Infect Dis 21: 31-36.

Vanittanakom N, Mekaprateep M, Sriburee P, Vanittanakom P, Khanjanasthiti P. 1995. Efficiency of the flotation method in the isolation of Penicillium marneffei from seeded soil. J Med Vet Mycol 33: 271-273.

Vanittanakom N, Cooper CRJ, Fisher MC, Sirisanthana T. 2006. Penicillium marneffei infection and recent advances in the epidemiology and molecular biology aspects. Clin Microbiol Rev 19: 95-110.

Viriyakosol S, Singhania A, Fierer J, Goldberg J, Kirkland TN, Woelk CH. 2013. Gene expression in human fungal pathogen Coccidioides immitis changes as arthroconidia differentiate into spherules and mature. BMC Microbiol 13: 121.

Wang H, LeBert V, Hung CY, Galles K, Saijo S, Lin X, Cole GT, Klein BS, Wuthrich M. 2014. C-type lectin receptors differentially induce Th17 cells and vaccine immunity to the endemic mycosis of North America. J Immunol 192: 1107-1119.

Webster RH, Sil A. 2008. Conserved factors Ryp2 and Ryp3 control cell morphology and infectious spore formation in the fungal pathogen Histoplasma capsulatum. Proc Natl Acad Sci 105: 14573-14578.

Wernicke R. 1892. Ueber einen Protozoenbefund bei Mycosis fungoides. Zentralbl Bakteriol 12: 859-861.

Wheat J. 1997. Histoplasmosis. Experience during outbreaks in Indianapolis and review of the literature. Medicine (Baltimore) 76: 339-354.

Wheat LJ, Slama TG, Eitzen HE, Kohler RB, French ML, Biesecker JL. 1981. A large urban outbreak of histoplasmosis: Clinical features. Ann Intern Med 94: 331-337.

Whiston E, Zhang Wise H, Sharpton TJ, Jui G, Cole GT, Taylor JW. 2012. Comparative transcriptomics of the saprobic and parasitic growth phases in Coccidioides spp. PLoS ONE 7: e41034. 
Woods JP. 2003. Knocking on the right door and making a comfortable home: Histoplasma capsulatum intracellular pathogenesis. Curr Opin Microbiol 6: 327-331.

Woods JP, Goldman WE. 1992. In vivo generation of linear plasmids with addition of telomeric sequences by Histoplasma capsulatum. Mol Microbiol 6: 3603-3610.

Woods JP, Goldman WE. 1993. Autonomous replication of foreign DNA in Histoplasma capsulatum: Role of native telomeric sequences. J Bacteriol 175: 636-641.

Woods JP, Heinecke EL, Goldman WE. 1998a. Electrotransformation and expression of bacterial genes encoding hygromycin phosphotransferase and $\beta$-galactosidase in the pathogenic fungus Histoplasma capsulatum. Infect Immun 66: 1697-1707.

Woods JP, Retallack DM, Heinecke EL, Goldman WE. 1998b. Rare homologous gene targeting in Histoplasma capsulatum: Disruption of the URA $5_{H c}$ gene by allelic replacement. J Bacteriol 180: 5135-5143.

Wuthrich M, Gern B, Hung CY, Ersland K, Rocco N, PickJacobs J, Galles K, Filutowicz H, Warner T, Evans M, et al. 2011. Vaccine-induced protection against 3 systemic my-
Thermally Dimorphic Human Fungal Pathogens

coses endemic to North America requires Th17 cells in mice. J Clin Invest 121: 554-568.

Wuthrich M, Ersland K, Pick-Jacobs JC, Gern BH, Frye CA, Sullivan TD, Brennan MB, Filutowicz HI, O’Brien K, Korthauer KD, et al. 2012. Limited model antigen expression by transgenic fungi induces disparate fates during differentiation of adoptively transferred $\mathrm{T}$ cell receptor transgenic $\mathrm{CD}^{+}{ }^{+} \mathrm{T}$ cells: Robust activation and proliferation with weak effector function during recall. Infect Immun 80: 787-797.

Youseff BH, Dougherty JA, Rappleye CA. 2009. Reverse genetics through random mutagenesis in Histoplasma capsulatum. BMC Microbiol 9: 236.

Youseff BH, Holbrook ED, Smolnycki KA, Rappleye CA. 2012. Extracellular superoxide dismutase protects Histoplasma yeast cells from host-derived oxidative stress. PLoS Pathog 8: e1002713.

Zhang Y, Li G, He D, Yu B, Yokoyama K, Wang L. 2011. Efficient insertional mutagenesis system for the dimorphic pathogenic fungus Sporothrix schenckii using Agrobacterium tumefaciens. J Microbiol Methods 84: 418-422. 


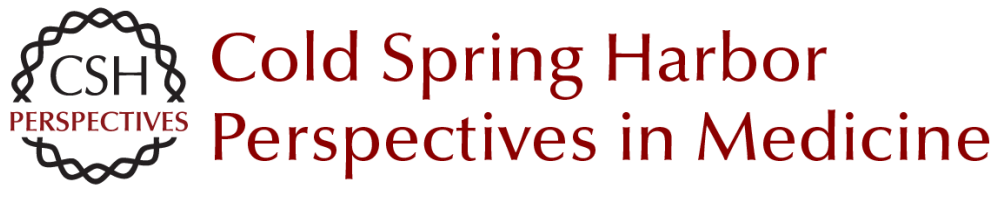

\title{
Thermally Dimorphic Human Fungal Pathogens--Polyphyletic Pathogens with a Convergent Pathogenicity Trait
}

\author{
Anita Sil and Alex Andrianopoulos
}

Cold Spring Harb Perspect Med 2015; doi: 10.1101/cshperspect.a019794 originally published online November 10, 2014

\begin{tabular}{|c|c|}
\hline Subject Collection Human Fungal Pathogens & \\
\hline $\begin{array}{l}\text { Evolutionary Perspectives on Human Fungal } \\
\text { Pathogens } \\
\text { John W. Taylor }\end{array}$ & $\begin{array}{l}\text { Thermally Dimorphic Human Fungal Pathogens-- } \\
\text { Polyphyletic Pathogens with a Convergent } \\
\text { Pathogenicity Trait } \\
\text { Anita Sil and Alex Andrianopoulos }\end{array}$ \\
\hline $\begin{array}{l}\text { Black Molds and Melanized Yeasts Pathogenic to } \\
\text { Humans } \\
\text { Anuradha Chowdhary, John Perfect and G. Sybren } \\
\text { de Hoog }\end{array}$ & $\begin{array}{l}\text { Mechanisms of Antifungal Drug Resistance } \\
\text { Leah E. Cowen, Dominique Sanglard, Susan J. } \\
\text { Howard, et al. }\end{array}$ \\
\hline $\begin{array}{l}\text { Fungal Pathogens: Survival and Replication } \\
\text { within Macrophages } \\
\text { Andrew S. Gilbert, Robert T. Wheeler and Robin C. } \\
\text { May }\end{array}$ & $\begin{array}{l}\text { Treatment Principles for Candida and } \\
\text { Cryptococcus } \\
\text { Laura C. Whitney and Tihana Bicanic }\end{array}$ \\
\hline $\begin{array}{l}\text { Innate Defense against Fungal Pathogens } \\
\text { Rebecca A. Drummond, Sarah L. Gaffen, Amy G. } \\
\text { Hise, et al. }\end{array}$ & $\begin{array}{l}\text { The Human Mycobiome } \\
\text { Patrick C. Seed }\end{array}$ \\
\hline $\begin{array}{l}\text { Antifungal Pharmacokinetics and } \\
\text { Pharmacodynamics } \\
\text { Alexander J. Lepak and David R. Andes }\end{array}$ & $\begin{array}{l}\text { Treatment Principles for the Management of Mold } \\
\text { Infections } \\
\text { Dimitrios } P \text {. Kontoyiannis and Russell E. Lewis }\end{array}$ \\
\hline $\begin{array}{l}\text { Human Fungal Pathogens of Mucorales and } \\
\text { Entomophthorales } \\
\text { Leonel Mendoza, Raquel Vilela, Kerstin Voelz, et } \\
\text { al. }\end{array}$ & $\begin{array}{l}\text { Adaptive Immunity to Fungi } \\
\text { Akash Verma, Marcel Wüthrich, George Deepe, et } \\
\text { al. }\end{array}$ \\
\hline $\begin{array}{l}\text { Functional Profiling of Human Fungal Pathogen } \\
\text { Genomes } \\
\text { Alexi I. Goranov and Hiten D. Madhani }\end{array}$ & $\begin{array}{l}\text { The Candida Pathogenic Species Complex } \\
\text { Siobhán A. Turner and Geraldine Butler }\end{array}$ \\
\hline $\begin{array}{l}\text { Aspergillus fumigatus and Related Species } \\
\text { Janyce A. Sugui, Kyung J. Kwon-Chung, Praveen } \\
\text { R. Juvvadi, et al. }\end{array}$ & $\begin{array}{l}\text { Fungal Morphogenesis } \\
\text { Xiaorong Lin, J. Andrew Alspaugh, Haoping Liu, et } \\
\text { al. }\end{array}$ \\
\hline
\end{tabular}

For additional articles in this collection, see http://perspectivesinmedicine.cshlp.org/cgi/collection/ 